\title{
Gitelman syndrome
}

\author{
INSERM
}

\section{Source}

INSERM. (1999). Orphanet: an online rare disease and orphan drug data base. Gitelman syndrome. ORPHA:358

A rare genetic renal salt-losing tubular disease, that is characterized by hypokalemic metabolic alkalosis with hypomagnesemia and hypocalciuria. 